\title{
PRAGMATIST AND POSTSTRUCTURALIST CRITICAL LEGAL PRACTICE
}

\author{
MARgaret JANE RADIN AND FRANK MichelmaN†
}

\section{INTRODUCTION}

Academic legal thought might be more concentratedly selfcritical than it usually is. We, its producers, could and should learn to be more habitually reflective

-about the social, cultural, and political conditions in which we produce our thought;

-about whether or how, in these conditions, it makes sense for us to cast our scholarship as arguments for or against any particular aspect of social practice or state of the social world;

-about precisely how-at what levels of ideology, choice, and action-we understand our evaluative scholarship to extricate itself from whatever it is we mean to be contending against; -about precisely how-at what levels of ideology, choice, and action-we imagine that our scholarship might work to move the world closer to whatever it is we mean to be contending for.

Not only might we acquire the habits and skills of such reflection, we ought to work on doing so. Such is the critical idea animating the symposium contributions from Professors Delgado, ${ }^{1}$ Schlag, ${ }^{2}$ and Winter. ${ }^{3}$ We think it is a serious and sensible claim.

† Margaret Jane Radin is Professor of Law, Stanford University. Frank Michelman is Professor of Law, Harvard University. Thanks to Regina Austin, Jack Balkin, Richard Delgado, Jerry Frug, Thomas Grey, Deborah Rhode, Fred Schauer, Pierre Schlag, Gerald Torres, and Steven Winter for their comments and criticisms.

1 See Delgado, Norms and Normal Science: Toward a Critique of Normativity in Legal Thought, 139 U. PA. L. REV. 933 (1991).

2 See Schlag, Normativity and the Politics of Form, 139 U. PA. L. REV 801 (1991) [hereinafter Schlag, Politics of Form].

3 See Winter, Contingency and Community in Normative Legal Practice, 139 U. PA. L. REV. 963 (1991) [hereinafter Winter, Contingency]. A like idea appears in previous writings of Schlag and Winter. See Schlag, Normative and Nowhere to Go, 43 STAN. L. REV. 167 (1990) [hereinafter Schlag, Normative and Nowhere to Go]; Winter, 
We mostly agree with it, and we find much that is compelling in the diagnoses offered by our cosymposiasts.

We do not agree, however, that it is especially helpful as part of the effort to advance an understanding of legal thought's situation and prospects

-to name "normativity" as legal thought's crucially problematic characteristic; or

-to set up rationalistic, monistic "grand theory"4-rigged of abstractive-deductive reasoning; 5 armed with compulsive moralizing prescriptions; ${ }^{6}$ girded by moral complacency, ${ }^{7}$ defensiveness, ${ }^{8}$ and self-enclosure ${ }^{9}$ and anchored in intellectual naïveté ${ }^{10}$-as the paradigm of problematically normative legal thought.

\section{A. Norrnativity as the Problem}

"What should we do? What should the law be? What do you propose?' . . asks normative legal thought."11 Normative, we thus understand, is what every prescriptive utterance is; normativity marks every saying addressed to a question of what someone should (or should not) do. Now, it seems obviously correct that normativity, thus sweepingly defined, is pandemic in legal thought and writing. But so is it pandemic, we would say, in thought and writing about legal thought-as represented, say, by the articles in this symposium.

Indeterminacy and Incommensurability in Constitutional Law, 78 CALIF. L. REV. 1441 (1990).

${ }^{4}$ Delgado, supra note 1, at 934; see also Schlag, Politics of Form, supra note 2, at 824-25, 839-40, 875-76, 879, 894-95, 899-901.

${ }^{5}$ See Delgado, supra note 1, at 960; Schlag, Normative and Nowhere to Go, supra note 3 , at 170 ("While not necessarily deductive in structure," normative thought based on an "abstract value" like equality "typically suffers from the same problem found in deductive legal thought. . . . [I]n the movement from the abstract to the concrete, the mediations between the two are either not to be found, or they are ... utterly unconvincing").

${ }^{6}$ See Delgado, supra note 1, at 935; Schlag, Normative and Nowhere to Go, supra note 3 , at 175 n.23, 178.

${ }^{7}$ See Delgado, supra note 1 , at 936.

${ }^{8}$ See Schlag, Normative and Nowhere to Go, supra note 3, at 180-82 \& n.41.

${ }^{9}$ See id. at 176; Schlag, Politics of Form, supra note 2, at 823-24.

${ }^{10}$ See Delgado, supra note 1, at 936; Schlag, Normative and Nowhere to Go, supra note 3, at 175; Schlag, Politics of Form, supra note 2, at 852, 874-77.

${ }^{11}$ Schlag, Normative and Nowhere to Go, supra note 3, at 177; see also Schlag, Politics of Form, supra note 2, at 802, 835-39. 
To work, in writing, at the displacement or destabilization of some named practice of writing (like normative legal thought) ${ }^{12}$ is already to exemplify and thereby to commend some different, some critically chastened, practice. ${ }^{13}$ Moreover, it is extremely difficult to carry on the work of destabilization without appearing to lapse into normative modes of discourse. Take, for example, this passage from an article by Schlag:

[T]his [talk-talk genre] simply argues that we should talk [some] new talk.... Variations on this old talk/new talk include the following: we should talk ... more normatively, [or] more contextually ... [etc.] or in that hopeful humanist way until we figure out what the hell we're doing up here 30,000 feet from earth arguing about how we should land. ${ }^{14}$

"We should talk more normatively" (WSTMN, for short) is the name of a certain sentence-the one that says we should talk more normatively. If uttering WSTMN is contemptible as just talk or as normative talk (and, to boot, as naively presupposing that how we talk, what we do, is within our power to decide ${ }^{15}$ ), then what is a reader supposed to make of the sentence that says that uttering WSTMN is contemptible on those grounds? It seems that saying that cannot (coherently) be an argument about whether or how we should (or should not) talk. How can one argue that what makes an utterance (or a genre) unworthy of attention or respect is that it is normative talk? To argue is to invoke the practice of argument, and that practice consists of normative talk. (Maybe you could try by some other means to remove that practice from society's repertoire, but you can't well do that by arguing about it.) But if this utterance of Schlag's is not argument, then what is it?

We believe that too many in the community to whom these writings are addressed will see Schlag here doing the very thing his utterance says should not be done-arguing prescriptively-and so charge him with a lapse of logic or consistency. We think such a charge would be too hasty. Schlag has not only been the first in these pages to call attention to the issue, he has been explicitly (and

12 See, e.g., Schlag, Politics of Form, supra note 2, at 932 ("[This article] is . . . in the nature of an attempt to help destabilize normative legal thought.").

${ }^{13}$ See $i d$. ("[W]hat should we do? This question arrives . . . too late .... We've been doing it since the beginning of this article, . . . trying to show a whole series of [normative routines] ... off the jurisprudential stage.").

${ }^{14}$ Schlag, Normative and Nowhere to Go, supra note 3, at 171.

${ }^{15}$ See id. 
helpfully) attentive to the delicacy of his position as an ardent assailant of normativity in scholarship. ${ }^{16}$ He directs our attention to the ubiquity and pertinacity of the problem he perceives. ${ }^{17}$

That ubiquity and that pertinacity, however, set rhetorical traps that we're not sure have been avoided. The issue, we emphasize, is not logic; it is rhetoric. Ilt is in the coin of persuasion that the question of the "logic" of Schlag's position finally pays. In the prevailing discourse of academics and intellectuals, "logic" functions as what Wittgenstein calls a "philosophical superlative";18 our use of the term here signifies that, try as they might, readers will find it difficult to see Schlag's position as other than self-contradictory. What accordingly strikes us is the rhetorical futility of argumentatively tying legal scholarship's failures of critical self-consciousness and methodological reflectiveness to its undeniable, but seemingly inexpungible, trait of normativity. For, even if by dint of great concentration we can occasionally and fleetingly glimpse a different possibility, normative moments do seem irrepressible from what any of us ever does as legal scholar, whether our study be first-order, of "law," or second-order, of "legal thought." To this issue we shall return in Part II and then again at the closing of this Comment.

\section{B. Grana! Theory as the Paradigm}

A paradigm is a core case. It is also a regulative model. Unmistakably, it seems to us, grand theory ${ }^{19}$ stands out as the core case of normative legal thought as that thought's critics present it. This is not surprising, given the critics' explanatory observation that grand theory today stands as the regulative model for legal thought in general. ${ }^{20}$ The critics are suggesting that all legal thought feels cultural pressure to measure its adequacy, as legal thought, against

${ }^{16}$ See Schlag, Politics of Form, supra note 2, at 925 (pleading confession and avoidance to charge of "performative contradiction"); infra note 125 and accompanying text.

${ }_{17}$ See, e.g., Schlag, Normative and Nowhere to Go, supra note 3, at 174 n.18 ("'[W]e can pronounce not a single destructive proposition which has not already had to slip into the form, the logic, and the implicit postulations of precisely what it seeks to contest." (quoting J. DERRIDA, Structure, Sign and Play in the Discourse of the Human Sciences, in WRTING AND DIFFERENCE 280 (A. Bass trans. 1978))). 1968).

${ }^{18}$ L. Wittcenstein, Philosophical Investigations $\S 192$ (G. Anscombe trans.

19 See supra notes 4-10 and accompanying text.

${ }^{20}$ See Schlag, Politics of Form, supra note 2, at 821, 843-47; Winter, Transcendental Nonsense, Metaphoric Reasoning, and the Cognitive Stakes for Law, 137 U. PA. L. REV. $1105,1206-24$ (1989). 
the norm of grand theory; and that this goes far to explain the invasion of all legal thought by relentless and, as they believe, incontinent prescriptivity. ${ }^{21}$

Again, our quarrel is not with the insight, but with the rhetoric the insight apparently prompts. Predominantly rationalistic/ prescriptive constructions of current legal-scholarly practice may still today be descriptively apt, and they do certainly direct attention to some important kinds of scholarly lapses from effective critical engagement with the world. Such constructions can also, however, deflect attention from other important kinds of lapses. They seem relatively blind to dangers of footloose atheoreticality, ${ }^{22}$ impotent particularism, ${ }^{23}$ complacent conventionalism, or traditionalism, ${ }^{24}$ and demobilizing self-suspicion. ${ }^{25}$ These latter kinds of dangers also plague some important varieties of normativity found in contemporary legal scholarship.

For purposes of critical insight and incision, the field of legal thought contains-arguably-not one normativity, but many normativities. The styles of scholarly activity that currently and colloquially fall under the heading of normative legal thought are diverse and in some respects incompatible. A partial listing, contrived for our own purposes here, would include the normative jurisprudences of autonomous doctrinal elaboration ("the artificial reason" of the $\left.{ } \mathrm{law}^{26}\right)$, instrumentalist economics, ${ }^{27}$ rights and principles, ${ }^{28}$ dialogism, ${ }^{29}$ poststructuralism, ${ }^{30}$ pragmatism, $^{31}$ feminism, ${ }^{32}$ and

${ }^{21}$ See Schlag, Politics of Form, supra note 2, at 822-24, 835-38.

22 See infra note 104.

${ }^{23}$ See infra text accompanying notes $103-04$.

${ }^{24}$ See infra notes $105-110$ and accompanying text.

${ }^{25}$ See infra notes 131-34 and accompanying text.

${ }^{26}$ Fried, The Artificial Reason of the Law or What Lauyers Know, 60 TEX. L. REv. 35, 39 (1981); see infra text accompanying notes 56-57.

${ }^{27}$ See infra notes 58-62 and accompanying text.

${ }^{28}$ See infra notes 63-85 and accompanying text. Under this heading, we would include both modern self-styled natural-law jurisprudential work, see, e.g., J. FINNIS, NATURAL LAW AND NATURAL RIGHTS (1980), and much of the modern jurisprudence of "interpretation," see, e.g., R. DWORKIN, LAW's EMPIRE (1986).

${ }^{29}$ By dialogic jurisprudences, we mean those concerned with defining the social and institutional conditions under which laws issuing from collective dialogic ("political") interactions deserve recognition as legitimate "self-government." See infra notes 86-97 and accompanying text.

${ }^{30}$ For now, readers can identify poststructuralism with the "deconstructive" method recently familiar in some "cls" attacks on other normative jurisprudences. Later, in Part III, we will justify putting poststructuralism on a plane with the others. See infra notes 47-50 and accompanying text. Some readers may wonder about the absence of postmodernism from this list, or indeed may identify postmodernism with 
critical race theory. ${ }^{33}$ Rhetorically treating all these jurisprudential practices as satellites of grand theory risks repelling or excusing too many normative practitioners from debates that ought to concern them.

\section{THE UBIQUITY OF THE NORMATIVE}

Consider legal positivism. It might be thought that legal positivism is the aspiration to legal thought without normativity. ${ }^{34}$ Legal positivism certainly is the tradition of insistence on screening value judgments out of law-finding, law-interpreting, and lawapplying. The positivist tradition's initial motivating impulse was, and it remains, the demand to distinguish the law that is politically enacted from the moral law (whatever it is) that may or not be so enacted. "Whether it be or not be is one enquiry; whether it be or not be conformable to an assumed standard, is a different enquiry." ${ }^{35}$

For Austin and Bentham, the motivation was progressive. ${ }^{36}$ In order to be able to change the law for the better, first we had to be able to realize that there can be laws, and moreover that laws can $b e$, independent of their being good or bad. Only thus could we have any hope of standing apart from the law so as to criticize and if necessary try to change it. Thus for Austin and Bentham (as more recently for $\mathrm{Hart}^{37}$ ), reform is the motive for cordoning valuational judgment away from the study of law as we find it. ${ }^{38}$ The central

poststructuralism (deconstruction). While postmodernism may be something of a contested concept right now, in this essay we will use the term in a broad sense to cover those styles of thought sharing philosophical commitments to anti-foundationalism, immanence, historicity, and epistemic political struggle. (Some writers also use pragmatism as the umbrella to signify this complex of commitments.) As they are practiced now, poststructuralism and pragmatism are postmodernist jurisprudences, as (largely) are feminism and critical race theory. See infra text accompanying notes 101-102.

${ }^{31}$ See infra notes 104-11 and accompanying text.

32 See infra notes $112-17$ and accompanying text.

${ }^{33}$ See infra notes 118-24 and accompanying text.

34 Delgado imagines his readers wondering whether "law without normativity [would] perhaps decline into positivism." Delgado, supra note 1, at 937.

${ }_{35} \mathrm{~J}$. AUSTIN, THE PROVINCE OF JURISPRUDENCE DETERMINED 184 (1954).

${ }^{36}$ H.L.A. Hart has detailed the elements of positivism in the thought of Bentham and Austin, whom he placed among "the architects of great reforms" of the nineteenth century. See Hart, Positivism and the Separation of Law and Morals, 71 HARV. L. REV. 593, 594-600 (1958).

${ }^{37}$ Id. at 621, 628-29.

${ }^{38}$ Cf. Delgado, supra note 1, at 959-60 ("Law might become, almost, a branch of 
teaching of their combined works is that reform is disenabled if the legal status quo is imagined as normatively ordained just by virtue of its being the status quo; and, conversely, reform is disenabled if the status quo becomes unidentifiable, a moving target à la Heisenberg ceaselessly yanked around by the values of its observers. ${ }^{39}$

In seeking to stand apart from law's normativity, the classical positivists were prompted by desire for reform. Thus, were the critics here aspiring to be our generation's neo- (or super-) legal positivists, they would have to notice that legal positivist aims (on our understanding of those aims), are ultimately normative (on the critics' broad understanding of the normative). Legal positivists contend that it will be better for us to put aside the mythology of law's inexorable convergence on the good and the right and so we ought to do so-not merely in the academic interest of clear thought, but in the social interest of justice and good government. Progressive positivism expects that when we do ascertain what a law is, we are going to exercise upon it our valuational judgment and act accordingly.

We won't press this suggestion too far. Contemporary legal positivisms do not always carry the nineteenth-century progressive motivation. Today, it is often conservatism that prompts insistence on separating questions of legal content from questions of value. For some conservative positivists, ${ }^{40}$ the aim is surely sometimes that of entrenching a normatively preferred, legal-doctrinal status quo against disruption by ideologically deviant reformist judges. ${ }^{41}$

hematology. We might begin to notice things like beggars or the countless other wounded that our system throws up. We might focus for the first time on subsistence claims, appreciate the dance between huge bureaucracies and those they serv(ic)e." (footnotes omitted)).

${ }^{39}$ Thus,

the ostrich does not get rid of her enemy by hiding her head in the sand. Slavery is not abolished, although we have persuaded ourselves that it has no right to exist. ... The Constitution will never be amended by persuading men that it does not need amendment. Nationai evils are only cured by holding men's eyes open, and forcing them to gaze on the hideous reality.

W. PHILLIPS, A REVIEW OF LYSANDER SPOONDER'S UNCONSTITUTIONALITY OF SLAVERY 3-4 (1847), quated in R. COVER, JUSTICE ACCUSED: ANTISLAVERY AND THE JUDICIAL PROCESS 154 (1975).

${ }^{40}$ See, e.g., Meese, Perspective on the Authoritativeness of Supreme Court Decision: The Law of the Constitution, 61 TUL. L. REv. 979 (1987).

${ }^{41}$ Cf. Schlag, Politics of Form, supra note 2, at 825 (noting that technical doctrinalists' criticisms of normative jurisprudence turn out to be "criticisms of particular normative orientations"). Ironically, this entrenchment of the status quo 
For others, ${ }^{42}$ insistence on law/value separation is rhetorically oriented towards the values connoted by the ideal of the Rule of Law, values that they claim are (at least partially) independent of legal content. Rule of Law values such as consistency, calculability, democracy, and official accountability depend, these conservative positivists say, on habits of respect for the fixed and "objective" character of legal content, as opposed to the variability and "subjectivity" believed to inhere in judgments of moral value. ${ }^{43}$ Thus they moralize against moralistic judges, who can subvert the Rule of Law by bringing to bear "their own subjective values" under the guise of adjudication.

If, despite their name and rhetoric, legal positivisms are irredeemably normative, what about contemporary legal antipositivisms? Do anti-positivists-can they-get beyond normativity? As do their positivist counterparts, anti-positivists assume a variety of stances. Some deplore the refuge from conscience that positivist rhetoric offers to legal actors, arguing that this rhetoric allows decisionmakers an escape from personal responsibility for the fleshand-blood consequences of their actions. Positivism, they say, encourages resort to mechanical jurisprudence ${ }^{44}$ and elevates the myth of legalism, or the virtue of fidelity to law-as-such, above and beyond ordinary moral consciousness. ${ }^{45}$ Less apparently moralistic are the modern anti-positivisms that proceed from philosophical or anthropological refutations of certain premises on which legal positivism's argument depends. The premises denied are what we may call separationist: that we can possibly hold separate from one another the activities of laying down ("making") the law, construing and following ("applying") the law, and criticizing ("evaluating") the law.

We can subdivide these separation-denying anti-positivisms according to their respective theories of inseparability. Some trace

is just what the nineteenth-century progressive positivists were fighting against.

${ }^{42}$ See, e.g., Scalia, The Rule of Law as a Law of Rules, 56 U. CHI. L. REV. 1175 (1989).

${ }^{43}$ See, e.g., Michelman, Takings, 1987, 88 CoLUM. L. REV. 1600, 1625-29 (1988); Radin, The Liberal Conception of Property: Cross-Currents in the Jurisprudence of Takings, 88 ColUM. L. REV. 1667, 1682-83 (1988). These conservative positivists thus focus on what we called the Heisenberg problem. See supra note 39 and accompanying text.

44 See Delgado, supra note 1, at 942-43; cf. Aleinikoff, Constitutional Law in the Age of Balancing, 96 YALE L.J. 943, 952, 962-63 (1987) ("The social science-like methodology of balancing instructed the judge to look for values 'out there'" in society.).

${ }^{45}$ See $\mathrm{R}$. Cover, supra note 39, at 150-54; Delgado, supra note 1, at 942-43. 
the impossibility of separation to human nature. They say that as embodied, thoughtful, reflective, socially situated beings we cannot avoid, or suppress from our law-saying pursuits, certain specific intuitions or convictions regarding good, evil, right and wrong. ${ }^{46}$ When such is the claim, a modern natural-law project is brewingnot what anyone within earshot would call non-normative.

But consider another, arguably deeper, variety of separationdenial. What of those (we are among them) who philosophically (small p) deny the very possibility of finally separating from one another the moments of cognition, imagination, evaluation, and articulate rendition of any social or intersubjective production, including law; or who deny the very possibility of holding quite separate our communicative acts of description, criticism, and prescription; and who deny, too, the very possibility of immunizing any of these moments from strong, cultural transmission? These denials raise questions not only for legal positivism but also for the kinds of natural-law projects that have customarily been pitted against it. In that sense, they are more than an anti-positivism. But can we go all the way and say they are non-normative? Can their utterers claim them as non-normative refutations not just of legal positivism and natural law, but of the possibility of any descriptive, prescriptive, or critical utterance seriously worth attempting or attending?

They can't successfully be claimed as that, because people listening can't seriously take them as that. When taken seriously, construed as communication, these philosophical separation-denials are themselves contentious utterances demanding attention. How can people hear them as denouncing the practice of soliciting, by contentious utterance, some change in practice?

Most importantly, all of these philosophical denials are utterances bound by their own (loosely speaking) postmodernist understandings of language, knowledge, power, value, and their interconnections. According to these postmodernist understandings, knowledge and power are interfused, and so are knowledge and value, knowledge and imagination, power and value, value and imagination, imagination and power. The fusing medium is language. There is no power-free language. There is, finally, no non-normative utterance. There are only kinds and degrees of normativity.

${ }^{46}$ See, e.g., J. FINNIS, supra note 28, at 81-97. 


\section{SOME CRITIQUes of NORMATIVITIES IN LEgal THOUGHT}

\section{A. Practice and Privilege}

We have already expressed our doubt that it is helpful, for purposes of the kinds of critiques of scholarship found in this symposium, to lump together, as normative, the various styles of activity currently manifest in written productions that are conventionally recognized as legal scholarship. For purposes of perspicuous critique, the field of scholarship, of writing, now marked as "legal" displays not one but many normativities.

Any listing will be contestable. None will describe a strict taxonomy of styles or projects, mutually exclusive and jointly exhaustive. (Our understanding of language practices would not allow for such an achievement.) But just in order to see how the work of unpacking might gro, take the list we've already offered of eight normative jurisprudences: the jurisprudences of autonomous doctrinal elaboration, instrumentalist economics, rights and principles, dialogism, poststructuralism, pragmatism, feminism, and critical race theory. Grant us the license of treating these, for now, as "our" legal normativities. ${ }^{47}$ Is there some distinct critical stance

${ }^{47}$ Let us here briefly mention some absentees from the list.

Public choice: We would regard instrumentally oriented work on public choice as a branch of instrumentalist economics whose (Hobbesian) anthropological premises it shares. What of descriptive or "positive" work in these modes, in contradistinction to intentionally instrumentalist or "normativen varieties? Whatever may be said of the conceptual viability of rigid fact-value distinctions, we would not deny the possibility of relatively nonprescriptive studies of law. In practice, however, we haven't seen, and don't anticipate seeing, many economics-inspired legal studies that lack a strong normative twist or inflection. See Michelman, Norms and Normativity in the Economic Analysis of Law, 62 MINN. L. RIvV. 1015, $1031-32$ (1978) (discussing normative tendencies in ostensibly positive scholarship); (f. Schlag, Normative and Nowhere to Go, supra note 3, at 172-73 (noting tendency of scholarship to hear the Zeitgeist speaking through it).

Legal realism: We understand it to be a mixture of positivist empiricism and early pragmatist instrumentalism; in this essay, we concentrate on its spiritual successors, the various kinds of contemporary critiques of the mythologies and mystifications holding together the legal status quo.

Law-and-society: In more traditional versions, its basic commitments are those of legal realism; in more modern versions, it coalesces with modern pragmatism.

Republicanism: We would say that recent normative jurisprudential essays on "civic republicanism," see generally The Civic Republican Tradition, 97 YALE L.J. 1493 (1988), partake, in varying mixtures, of the jurisprudences of dialogism and of rights and principles. 
(discourse, practice) that is aptly generalizable, as anti-normative, to all of these jurisprudential frameworks? We doubt it.

Some may object that we have already sabotaged the inquiry by (mis)locating poststructuralism as a normative "jurisprudence" on a plane with the others. By that move, the objection would run, we fend off recognition that poststructuralism is the anti-normative, anti-legal, critical stance (discourse, practice), we profess to be seeking. In older terms, we would be charged with a category mistake; in newer terms, we would be charged with failing to privilege poststructuralism. ${ }^{48}$

Our answer to that sort of objection is already contained in the objection's demand for a privilege, indeed an undislodgeable, privileged privilege. Postmodernists, we think, are committed not only to the view that at any moment some stance must be privileged, but to the view that it could be any available stance and that no privilege is stabilized against dislodgment. ${ }^{49}$ If there can be no

Law-and-literature: It is best conceived, we suggest, not as a separate normative style, but as a congeries of various normative styles in which practitioners draw material and inspiration from literature and literary studies.

Postmodernism: As we explained earlier, see supra note 30 , we understand postmodernism in a broader sense than poststructuralism, to refer to a set of understandings common to pragmatism and poststructuralism, and (largely) also to feminism and critical race theory.

${ }^{48}$ Pierre Schlag has said that

[i]f traditional legal discourse succeeds in transforming deconstruction into just another technique, just another theory, just another method for making arguments, ... [d] [econstruction will become powerless to subvert and displace the categorial regime in force precisely because it will have become subsumed with that very same categorial regime-the one that systematically transforms intellectual endeavors into just another technique, just another theory, just another method. . . . But to transform deconstruction into any of these things is to turn deconstruction into precisely what it seeks to resist and displace. To transform deconstruction into a theory, etc. is to relocate deconstruction and confine it to the already inscribed logocentric matrices of traditional legal thought. . . . The error here is the homogenization and neutralization of the different subversiveness of deconstruction through its assimilation with approaches that have already been reduced to the status of mere theories, techniques, methods, etc.

Schlag, "Le Hors de Texte, C'est Moi": The Politics of Form and the Domestication of Deconstruction, 11 CARDOZO L. REV. 1631, 1636-37 (1990); cf. Schlag, Normative and Nowhere to Go, supra note 3, 169 n.7 (observing that adherents of "fundamentalist" (i.e., value-choice oriented) conceptions of politics tend to "miss" the political point of "postmodernism" precisely because postmodernism's point is "to decenter and displace this traditional conception of politics").

${ }^{49}$ So if we have a disagreement with Schlag here, it isn't with his warning about deconstruction's loss of critical bite when reduced to a mere "method" that one 
privilege over privileges, then the claim for a privileged status vis-àvis the other "jurisprudences," as critique of them all rather than fellow target of criticism, is no less available to any other "jurisprudence" on our list than it is to poststructuralism. To claim otherwise-to insist on a privilege over privileges-would be to restore a foundation. Poststructuralism, rejecting foundations, here joins pragmatism: ${ }^{50}$ which stance stands as critique and which others stand as targets is always and strictly a matter of (i) occasion or focus, and (ii) perspective or interest; it is not a fixed or stable matter of conceptual structure or logical inference.

In what remains of this essay, we will play out the diversity of legal normativities as seen from both poststructuralist and pragmatist critical stances. Three cautions, before we proceed:

First: Under pressures of exposition, we set up ideal-types of poststructuralism and pragmatism. We try, however, not to think of these isms as ever in practice separate and mutually exclusive. We try to see them always as different moments in a critical practice that requires both.

Second: We also see the two as different philosophical temperaments or frames of mind. We do not, however, think of these different temperaments as exclusively inhabiting different people. Specifically, we are not seeing ourselves as "pragmatists" jousting with other symposiasts here whom we see as "poststructuralists." We speak for and against both stances. When we have an identified exemplar in mind of one or another tendency, we name the exemplar.

Third: We do, however, work harder here to explain pragmatism's contribution to legal-scholarly critical practice than we do poststructuralism's contribution. We emphasize more the deficiencies of the poststructuralist moment neglecting the pragmatist than those of the pragmatist moment neglecting the poststructuralist. That is because, as matters stand today, explaining pragmatism is

"applies," to (say) the resolution of legal issues or the criticism of legal discourses. We simply want to resist any suggestion that the other (normative, legal) discourses are stuck in the subordinated (disprivileged, supplementary) position of "mere techniques, methods." We want to insist on dangerous supplementarity, on flippability. See, e.g., Balkin, Deconstructive Practice and Legal Theory, 96 YALE L.J. 743, 755-61 (1987) (explaining deconstructivist notions of reversibility of privilege and (dangerous) supplementarity). We want to insist that the other discourses can also be thought in the privileged position of critical stance or practice.

${ }^{50} \mathrm{As}$ it will again; and again; and again.... See infra notes 73-85, 91-100, \& 125 and accompanying text. 
the harder and more urgent work. In today's legal-academic discussions, pragmatism is the less developed and spongier term. If, today, you call your legal-scholarly work deconstruction, you run a real risk of getting nailed for either misuse of the term or misconduct of the practice. Calling your work pragmatist runs you no such risk, but does run you another: pragmatism still tends to get dismissed as a buzzword or a poor excuse for thought. "We are all poststructuralists now" may start a row. "We are all pragmatists now" merely gets you a yawn. We are out to change that, in part by investigating the interaction of poststructuralism and pragmatism.

\section{B. Poststructuralists and Pragmatists: Ideal-Types}

The poststructuralist moment in critical practice is conceptual, diagnostic, and global. It fastens on intellectual structures and denies their analytic probity. It indicts whole discourses and all their works by showing their conceptual, categorical frameworks in a state of collapse. In the poststructuralist frame of mind, we search for dialectical fault lines implanted in discursive frameworks. We deflate argumentative paradigms built around a characteristic set (one for each target jurisprudence) of categories, distinctions, and oppositions. We show their failures of closure-perhaps by exposing addiction to a "fundamental contradiction, ${ }^{n 51}$ perhaps by exposing tactics of recursion and deferral. ${ }^{52}$

The pragmatist moment in critical practice is, by contrast, empirical, epidemiological, and local. It notices characteristic kinds of errors or biases that recur when target discourses are deployed by nonideal-incompletely committed and assiduous-practitioners caught in specific cultural environments. ${ }^{53}$ The pragmatically minded critic does not deny or ignore conceptual instability. Neither does she hold that conceptual instability per se discredits a framework. Indeed, she does not especially care to discredit any discourse intrinsically or holistically. She rather seeks to evaluate the discourse in use (given its conceptual instabilities) by ordinarily complacent, culturally bound practitioners. She asks, for example, about the tendency of the discourse, in its cultural setting, to focus

51 See Kennedy, The Structure of Blackstone's Commentaries, 28 BUFFALO L. REV. 209, 211-13 (1979).

52 See Schlag, Cannibal Moves: An Essay on the Metamorphoses of the Legal Distinction, 40 STAN. L. REv. 929, 961 (1988); see also Dalton, An Essay in the Deconstruction of Contract Doctrine, 94 YALE L.J. 977 (1985).

${ }^{35}$ For the record: We are all nonideal; we are all incomplete; we are all lazy. 
on some problems and blur others. Pragmatically successful critique does not necessarily mean that practitioners give up use of the framework. It may mean, rather, that they watch out and correct for biases to which the culturally situated framework is prone.

For purposes of the illustrative discussions to follow, consider four strains in the prevailing intellectual culture of contemporary America: (i) formalist, disposed to hinge the possibility of cogency in argument or judgment (concerning truth and error, right and wrong) to "pre-established, noncontroversial criteria;" 54 legalist, disposed to think that power strictly directed by fixed, general rules is categorically safer, more benign, than power entrusted to exercises of situated judgment; (iii) privatist, disposed to regard "exercises" of state power as categorically more dangerous to freedom and welfare than "contests" of private or market powers; and (iv) capitalist, disposed to locate value in exchange, as price. ${ }^{55}$

\section{Autonomous Doctrinalism}

Our own discussion of legal positivism, above, ${ }^{56}$ intimates the poststucturalist moment in critique of autonomous doctrinalism. We attack as untenable certain dichotomies on which that jurisprudence rears itself: for example, "following" vs. "making" law, or Rule of Law vs. personal rule. If such an attack were a terminus in thought, then critique would end by proposing, explicitly or implicitly, rejection of doctrinal argument from serious legal work.

If, however, critical practice also contains a pragmatic side, then while we will not deny that the conceptual structures of doctrinalist discourse are liable to collapse, we will allow that we might often be able, in practice, to maintain a local, working separation among our senses of (i) "the rules," (ii) "the facts," and (iii) the ends to be served. That working separation might or might not be enough to allow for appreciably consistent and purposive rule application. We have to look and see. The pragmatic moment is that of bracketing possibility and looking at. practice. In that practice we look, pragmatically, for characteristic errors and biases. Perhaps we observe how, in a dominantly legalist and privatist cultural environment, judicial doctrinalists tend in practice to find rule application

\footnotetext{
54 Schlag, Politics of Form, supra note 2, at 893.

$55 \mathrm{Or}$, more generally, reductionist, disposed to think that reasoned decision requires a common measure for all matters in contention.

${ }_{56}$ See supra text following note 34 .
} 
too simple. Perhaps we see them often failing to work all the way through the mazes and hierarchies of rules in a mature legal order, to the point of laying bare the order's unresolved conflicts and gaps; or we see them refusing to legislate in the gaps as Hart urges they should forthrightly do. ${ }^{57}$ Doctrinalists are thus too often too quick, the pragmatist critic may end by saying, to deny responsibility for moral outrage on the ground that their hands are tied.

\section{Instrumentalist Economics}

The normative jurisprudences of economics tend to be reductionist, conceiving of all things people value as monetizable, commensurable in the currency of demand, and they tend to be formalist, treating allocative efficiency-wealth maximization-as the organizing end of social ordering by law. These two commitments structure a conceptual field that lends itself to easy deconstruction: one simply points out that (i) a system of legal rules can be adjudged wealth-maximizing only relative to a given configuration of demand; (ii) configurations of demand are conceptually indistinct from distributions of wealth; and (iii) distributions of wealth are what legal rule choices determine.

Critiques of normative economic jurisprudence move out in various ways from this central analytical collapse to contend that economic analysis can do no more than provide a cover of legitimacy to political choices otherwise decided. ${ }^{58}$ They show that the economically prescribed system of legal rules depends on the arbitrary order in which particular rules are taken up for consideration. Or they show that the prescription for any rule of law depends on an arbitrary assumption about which way the rule (or the "entitlement" it controls) is already hypothetically set; or, alternatively, it depends on whether we measure willingness to pay by what one would "offer" to acquire the entitlement or by what one

57 See Hart, supra note 36 , at 600 .

${ }^{58}$ See, e.g., Kennedy, Cost-Benefit Analysis of Entitlement Problems: A Critique, 33 STAN. L. REV. 387, 388 (1981) (noting that to use economic analysis we have to make value judgments that are political). 
would "ask" in exchange for parting with it. ${ }^{59}$ Such is the work of poststructuralist critical moments.

In one respect, a pragmatist inflection will tend to make critique more accommodationist. Perhaps, rather than simply decry the conceptual shambles of the whole question of efficiency in entitlement, we pragmatically look at this or that entitlement specifically at issue and ask how destabilizingly large a fraction of wealth (demand) its assignment controls. At any rate, we would not without looking insist that "the offer-asking problem" cannot ever, in practice, be managed or checked so as to maintain the local workability and intelligence of cost-benefit analyses of legal rules.

In another respect, however, the pragmatic emphasis in critical practice is more demanding than the deconstructionist. If the pragmatist-minded critic is willing to bracket the intelligibility or coherence of wealth maximization as a goal for law, she is equally insistent on questioning its aptness. She questions the fit between wealth and flourishing.

The pragmatically minded critic will harp on characteristic ways in which economic analysts of legal rules tend toward incompletion in their practice. She may try to show how analysts in a dominantly formalist, legalist, privatist, and capitalist culture suppress certain kinds of, shall we say, obstreperous values. ${ }^{60}$ She may show the analysts ignoring costs, like disruption of community, that powerwielders-judges, administrators, consulting experts to lawmakerscannot handle according to rule. Perhaps the magnitude of cost is speculative. Perhaps the "cost" consists of blocking desire that is beyond price even in theory, let alone practice; for example, desire for kinds of community that don't reduce desire to the "preferenc-

59 See, e.g., Kelman, Consumption Theory, Production Theory, and Ideology in the Coase Theorem, 52 S. CAL. L. REv. 669 (1979); Spitzer \& Hoffman, A Reply to Consumption Theory, Production Theory, and [deology in the Coase Theorem, $53 \mathrm{~S}$. CAL. L. REV. 1187 (1980); $c f$. E. HOFFMAN \& M. SPITZER, THE DIVERGENCE BETWEEN WILLINGNESSTO-PAY AND WILlINGNESS-TO-ACCEPT MEASURES OF VALUE 42 n.14 (Calif. Inst. of Tech. Social Science Working Paper No. 755 Nov. 1990) (stating that the authors "now believe that reliable evidence suggests that Kelman's central intuition may have been correct").

${ }^{60}$ See, e.g., Michelman, Ethics, Economics, and the Law of Property, in NOMOS XXIV: ETHICs, ECONOMICS, AND THE LAW 3, 21-24, 33-34 (J. Pennock \& J. Chapman eds. 1982) (doubting the empirical basis for attributions of "preferences" for various "institutional roles, states, [and] experiences"); Radin, Market-Inalienability, 100 HARV. L. REV. 1849, 1878 (1987) (arguing that " ${ }^{\text {[ }}$ r]easoning in market rhetoric, with its characterization of everything that people value as monetizable and fungible, tends to make it easy to ignore . . . other "costs" that are not readily monetizable, such as personal and community disruption). 
es" of deracinated, disembodied selves having attributes for sale. The pragmatist will show the distortive effect, in a dominantly capitalist culture, of reductionist pressure to give "due" consideration to every desire by pricing it. ${ }^{61}$

The pragmatic critical practitioner will further show how, in a dominantly privatist culture, analysts seem either not to notice or not to care that the "political" processes to which they buck the obstreperous value issues (including issues of justice in distribution) may very possibly never seriously consider these issues. ${ }^{62}$ The result, she will point out, is that their framework does not, in practice, encourage us to recognize the values that economic jurisprudes insist (not illogically) that "we" could find ways of recognizing.

\section{Rights and Principles}

By rights-centered jurisprudences, we mean those for which a key to the kingdom of freedom-in-society is universality of recognition of the worth of persons, institutionally expressed by consistency in treatment as persons. Such a jurisprudence thus centers on claims to certain kinds of treatment that an ideal legal order prefers or entrenches, and the order's modes of defining and attributing such claims.

From the poststructuralist vantage, all such jurisprudences are "riven by internal conflict between the demands for abstraction and for concreteness in legal norms. " 63 Universality implies transcendence of difference, a reach for consensus. So it requires that an order's fundamental premises of right be cast at very high levels of abstraction. But from highly abstract principles of right, convinc-

61 The capitalistic context is what (sometimes) makes the fact of pricing or the fact of exchange a problematic commodification. See Radin, Justice and the Market Domain, in NOMOS XXXI: MARRETS AND JUSTICE 165, 185-86 J. Pennock \& J. Chapman eds. 1989) (arguing that in an ideal world the mere fact that money changes hands need not undermine personhood and community, although it may do so in the nonideal world of extensive commodification).

62 See, e.g., M. POLINSKY, AN INTRODUCTION TO LAW AND ECONOMICs 9-10, 115-17 (1983) (arguing that the distribution of income is best adjusted through the government tax and transfer system). But see Kronman, Contract Law and Distributive Justice, 89 YALE L.J. 472, 498-510 (1980) (arguing that liberal theory's tendency to prefer taxation to regulation of private exchange as a means of redistribution is unwarranted).

${ }^{63}$ Michelman, Justification (and Justifiability) of Law in a Contradictory World, in NOMOS XXVIII: JUSTIFICATION 71, 80 (J. Pennock \& J. Chapman eds. 1986) (following Kennedy, supra note 51). 
ingly neutral and consistent treatments of concrete cases cannot be derived. ${ }^{64}$

From this seed grow the distinguished critiques of rights-as inherently indeterminate or inherently too abstract to do more than provide rhetorical cover for hegemonic power-produced by writers like Dalton, ${ }^{65}$ Gabel, $^{66}$ Klare, ${ }^{67}$ Olsen, ${ }^{68}$ and Tushnet. $^{69}$ These critiques all make use of the antinomy of universality and consistency-the perception that the abstraction required of propositions of right by professions of universality forecloses the prospect of determinate (hence consistent) application to concrete cases. The critiques move from this perception to the observation that whatever sense of consistency (hence determinacy) we achieve in legal applications depends on partisan impositions that belie universalism. Abstract, universalistic norms require specific constructions of social reality to make them concretely operative, say poststructuralist-inspired critics of rights-based jurisprudence. Those constructions are bound to reflect the partisan interests and experiences of the powers-that-be. ${ }^{70}$

For example, it can be shown that abstract, universalistic propositions about rights of civil liberty and civil equality yield no determinate (hence can underwrite no consistent) answer to the question of government regulation of pornography or racist speech. ${ }^{71}$ It follows that those who have confident, "law-like"

${ }^{64}$ See Schlag, Politics of Form, supra note 2, at 874; supra note 5 (quoting Schlag, Normative and Nowhere to Go, supra note 3 , at 170 ).

${ }^{65}$ See Dalton, supra note 52.

${ }^{66}$ See Gabel, The Phenomenology of Rights-Consciousness and the Pact of the Withdrawn Selves, 62 TEX. L. REV. 1563 (1984:).

67 See Klare, The Public/Private Distinction in Labor Law, 130 U. PA. L. REV. 1358 (1982).

${ }^{68}$ See Olsen, Statutory Rape: A Feminist Critique of Rights Analysis, 63 TEX. L. REv. 387 (1984).

${ }^{69}$ See Tushnet, An Essay On Rights, 62 TEx. L. REV. 1363 (1984) [hereinafter Tushnet, Essay]; Tushnet, Rights: An Essay in Informal Political Theory, 17 PoL. \& Soc'Y 403 (1989) [hereinafter Tushnet, Rights].

${ }^{70}$ See Balkin, supra note 49 , at 761-64.

${ }^{71}$ See Delgado, Campus Antiracism Rules: Constitutional Narratives in Collision, 85 Nw. U.L. REv. 343, 345-48, 375-83, 386-87 (1991) (describing "indeterminacy" in classifying racist speech as a "first amendment" or "equality-protecting" problem); Michelman, Conceptions of Democracy in American Constitutional Argument: The Case of Pornography Regulation, 56 TENN. L. REV. 291, 305-09 (1989); Lawrence, If He Hollers Let Him Go: Regulating Racist Speech on Campus, 1990 DUKE L.J. 431, 438-49 (arguing that content-based regulation of racist speech may be constitutionally required in some circumstances); cf. Grey, Civil Rights vs. Civil Liberties: The Case of Discriminatory Verbal Harassment (forthcoming SoC. PHIL. \& POL'Y (1991)) (presenting pragmatist 
answers to the question produce them out of partisan views of social relations. In America today, the prevailing, confident answers are those that privatistically and formalistically construct state power as tendentiously more dangerous to freedom in general than private or market power and that legalistically construct contextualized judicial judgment ("balancing") as tendentiously more dangerous than decision dictated by rule. ${ }^{72}$ In this way, deconstructive critiques of rights open the way to seeing how law depends on particular constructions of social reality to concretize its universalistic pretensions.

Readers stung by such critiques too often read them as nihilistically intending their exposés of structural instabilities in normative discourses of rights as sufficient refutations of the discourses or their liberatory potentials. But often one can find in the critiques a pragmatic as well as a deconstructive side. In the pragmatic moment of critical practice, one may understand the structural weakness of a target discourse not as its already fatal flaw, but as its working interface with surrounding cultural dispositions. ${ }^{78}$ One may then consider whether the discourse is salvageable by work on those dispositions. ${ }^{74}$ When the pragmatic critic's answer is No, as it sometimes is, ${ }^{75}$ no event of nihilism has transpired. ${ }^{76}$

approach to hate speech issue which requires accommodation in practice of incommensurable perspectives).

72 See Michelman, supra note 71, at 309-18.

73 When we are thinking deconstructively, domination (supplementarity) appears immediately in the foreground of thought itself-in thought's (or at any rate "Western" thought's) irrepressible nature, in the confounding logic of Western consciousness, in conditions of reflection. See, e.g., Balkin, supra note 49, at 747-48 (explaining Derrida's notion of the metaphysics of presence). Turning pragmatic, we look also to the pre-reflective background, to conditions ("forms") of life. We look to reflection's traffic with its contingent context, its socio-cultural environment. See supra notes 56-62; infra notes 77-97 \& 122-24 and accompanying text. We see reflection's crises-conceptual stresses and imminent collapses-as the vortices of that traffic.

74 See Cover, The Supreme Court, 1982 Term-Foreword: Nomos and Narrative, 97 HARV. L. REV. 4, 10 (1983) ("To live in a legal world requires that one know not only the precepts, but also their connections to possible and plausible states of affairs.").

${ }^{15}$ See, e.g., Tushnet, Essay, supra note 69, at 1371-75, 1382-84 (arguing pragmatically against attempts to rehabilitate rights discourse in prevailing intellectual climate); Tushnet, Rights, supra note 69, at 412, 422 (same).

${ }^{76}$ Whether or not "nihilism" can be pragmatic, compare Stick, Can Nihilism Be Pragmatic?, 100 HARv. L. REv. 332 (1987) with Singer, Legal Realism Now (Book Review), 76 Calif. L. REv. 465 (1988) (reviewing L. KaLMaN, LEGal REALISM AT YALE: $1927-1960$ (1986)), it seems clear that pragmatism cannot be nihilism. 
Of course, the answer may not be No. The trouble with universalist rights discourse (the pragmatically minded critic might say), isn't simply structural instability; it is also complacency, incomplete commitment to go all the way down the emancipatory path that the discourse opens. ${ }^{77}$ More specifically, the trouble is that complacent rights practitioners in a dominantly privatist-legalist culture too readily fly from the stresses of public commitment to the refuge of abstract rule. ${ }^{78}$ In the case of our example, the stress of public commitment means facing the conundrum of subordination recycled, universality subverted, through abstract, formal freedom of speech (the freedom of derogatory utterance that reentrenches subordination). The refuge of abstract rule means cleaving to privatistic, formal equality-the absolute ban on state-sanctioned, content-biased regulation. The pragmatist feels drawn to face the conundrum and deal with it, perhaps by the use of judgment in context-"balancing" or "line-drawing."

Thus, in a pragmatist moment of critical legal practice, it will not necessarily be the discourse of universalism, rather it may be the cultural context of privatism/legalism that we hold accountable for tendentiously conservative abstraction. Pragmatism here means methodological doubt that the universalistic idea of rights is necessarily abstracted and removed from the concrete cruelties of the day. Just as, in a dominantly privatist and legalist environment, the lazy economist is prone to ignore values that resist monetization and the lazy doctrinalist suppresses conflicts and gaps, so, in such an environment, the lazy Rechtslehrer is prone to ignore oppression in the name of principle.

The passions of rights-critics are not misplaced: people can discuss abstract freedom and equality forever and never lay a glove on subordination. Freedom can turn out to mean trading who you are and what you've got-markets as usual. Free speech can turn out to mean pornography and racist hate. But it is still possible to think that the passion should be directed not against the very thought of

77 See Winter, supra note 20, at 1232 ("Rights are about the course of the future, and that future is made only through the commitments of real people.").

78 See Cover, supra note 74, at 57-59, 66-67 (describing the Supreme Court justices deciding Bob Jones University v. United States, 401 U.S. 574 (1983), as "wary and cautious actors" displaying "some eloquence" but "no commitment").

${ }^{79}$ See Michelman, supra note 71 , at 308-09, 318-19. But see infra notes 103-05 and accompanying text (noticing prą̧matism's weakness for radical particularism). For an example of pragmatic line-drawing, see Grey, supra note 71 (proposing narrowlydrawn regulation to deal with hate speech on campus). 
rights, but rather at the characteristic failings of nonideal rights practice in our specific cultural context.

The knowledge of peoples of color, for example, has been that it is not just legal consciousness but racial consciousness that supports (among whites) the prevailing power dispensations in American society. In the experience of peoples of color, the universalistic idea of rights, indeed the very formalism of the idea, can become reconstructive. ${ }^{80}$ It can serve as a probe to the feeling-or if not to the feeling then to the nerve, to the motivation-of dominant group members who do not feel the "substantive" force of expostulations of need, ${ }^{81}$ or calls for reparation, ${ }^{82} \mathrm{com}$ ing from people they have learned to see as different and subordinate. The trick is to make dominant society confront itself in the mirror of its own most idealistic professions. ${ }^{83}$ Pragmatist critical practice here means seeing the possible effects, in practice and in context, of the formalism that is a hallmark of the jurisprudence of rights.

You can then, perhaps, take up where deconstruction sometimes ends. Deconstructions of rights sometimes end in the knowledge that abstract rights cannot be rendered concrete without help from partisan constructions of social reality. ${ }^{84}$ You adopt that knowledge. You want to use whatever is at hand in the work of dislodging bad-subordinative-constructions. One of the things at hand is the abstract, the aspirational, the formal idea of rights. ${ }^{85}$

${ }^{80}$ See Crenshaw, Race, Reform, and Retrenchment: Transformation and Legitimation in Antidiscrimination Law, 101 HARV. L. REV. 1331, 1357 n.99, 1364-65, 1381-82 (1988); Williams, Alchemical Notes: Reconstructing Ideals From Deconstructed Rights, 22 HARV. C.R.-C.L. L. REV, 401, 404-06 (1987).

81 See Crenshaw, supra note 80, at 1341-46; Fraser, Talking About Needs: Interpretive Contests as Political Conflicts in Welfare-State Societies, 99 ETHICs 291, 293-94 (1989).

82 See Delgado, The Imperial Scholar: Reflections of a Review of Civil Rights Literature, 132 U. PA. L. REV. 561, 566-73 (1984); Matsuda, Looking to the Bottom: Critical Legal Studies and Reparations, 22 HARV. C.R.-C.L. L. REV. 323, 372-78 (1987).

83 In Schlag's ironic formulation, the trick is to work "freedom" as a "word for getting [us] to do what [we] don't want to do." Schlag, Normative and Nowhere to Go, supra note $\mathbf{3}$, at 185 . This statement, too, contains its dialectic. What Schlag attacks is domination by means of pseudo-dialogue. Yet "freedom" used that way also performatively commits the dominators to the universalist ideal. Sometimes the effect is counter-subordinative. When it is, irony is doubly served.

84 Our understanding here of deconstruction's contribution to legal criticism echoes that of Jack Balkin. See Balkin, supra note 49, 744-45, 755, 770 ("[D]econstruction of a privileging in a limited area of . . . doctrine exposes," and invites us to investigate, "a more pervasive underlying ideology" of "unquestioned . . . assumptions" that inform our doctrine at large.).

${ }^{85}$ Note that appealing to rights need not be an alternative to storytelling, see 


\section{Dialogism}

The jurisprudence of rights pragmatized-colloquialized, contextualized to conditionss of cultural pluralism-shades into the jurisprudence of dialogue.

Dialogic jurisprudes focus on the search for social conditions, including cultural understandings of the ideas of law, legality, and rights, under which collective determinations of aspects of social life are consistent with personal freedom. They ask how the laws and rights issuing from dialogic interactions can possibly merit recognition as self-government that constitutes, reflects, and furthers such freedom-for all, universally. Jurisprudential dialogism belongs to a distinct tradition of political-moral thought, "in which nonconsensual influences on the self are perceived as coercive invasions of the autonomy of the subject, to be overcome by" participatory politics. ${ }^{86}$

From the pragmatist vantage, what is the incomplete dialogist's telltale complacency? Surely, it is overconfidence, unexamined trust, in the extent to which "we" can all talk meaningfully, persuasively, and yet nondominatively to each other. ${ }^{87}$ The complacent dialogist admits social plurality but misgauges its depth. Maybe she sees a "society" strained by conflicts of interests. Maybe she does not focus hard enough on those who stand estranged from this society, this "we," by epistemic distance, by profounder conflicts of worldviews. Maybe she too readily assumes that all the members of society share enough in language and self-conception to allow for undominated dialogue ... if only just up to and not beyond a certain point.

Such a point might be that of an "overlapping consensus." Consensus on what? Perhaps on the dangers and evils of pseudodialogic domination, majoritarian or bureaucratic tyranny. Also, then, on the consequent presumptive prudence of restricting the state to the promulgation of abstract rules, or to regulating in the "public" sphere, as its chief or characteristic means for realizing the

Delgado, Storytelling for Oppositionists and Others: A Plea for Narrative, 87 MICH. L. REV. 2411 (1989), but may be an accompaniment.

${ }^{86}$ Post, The Relatively Autononious Discourse of Law, in LAW AND THE ORDER OF Culture (R. Post ed. forthcoming 1991).

${ }^{87}$ See, e.g., Bell \& Bansal, The Republican Revival and Racial Politics, 97 YALE L.J. $1609,1610-13,1616$ (1988) (arguing that updated versions of republican theory espoused by Michelman and Sunstein fail to admit the difficulties and dangers posed by racial domination and estrangement for ideals of dialogic reconciliation). 
basic liberties of persons. ${ }^{88}$ But what, the pragmatist-minded critic may ask, has that construct, redolent of privatist-legalist culture, to say about entrenched racism and sexism speaking through "private" preferences, or about entrenched poverty based on "private" markets? How can we hope to approach or preserve a state of undominated dialogue without concerted assault on such stratifications? ${ }^{89}$ Yet how could we mount that concerted assault, with our politics under prohibition against non-neutral intervention into the social processes of ideological exchange? ${ }^{90}$

From the poststructuralist vantage, on the other hand, dialogism's dilemma is that dialogue (insofar as it is not disguised coercion) presupposes community; but community is not, finally, a matter of will or sympathetic exertion but rather is a contingency of cognitive structures into which we are thrown. ${ }^{91}$ Deconstruction finds in the very idea of self-emancipatory political dialogue a disturbing conceptual instability: the collapse of conceptual walls between personal and societal, internal and external, self-active and compulsive; and the concomitant confusion of persuasion (choice, freedom) with prescription (necessity, compulsion). The dialogic idea entails "prescription that specifies in advance the conditions under which dialogue will count as persuasion rather than coercion." If this prescription is itself coercion-but what else could it be?-then how can dialogue be undominated, a medium of selfemancipation?

To the pragmatist temperament, no such purely conceptual bind can be terminal to the practical pursuit of democratic, collective self-government. The pragmatist may still find it right to pursue the issue of the social and cultural conditions of self-government for all-universally-through democratic politics. ${ }^{93}$ Still, the question

${ }^{88}$ See R. RORTY, CONTINGENCY, IRONY, AND SOLIDARITY Xiv-xv, 63, 84-85, 120, 198 (1989); Rawls, Justice as Fairness: Political Not Metaphysical, 14 PHIL. \& PUB. AFF. 223, 225, 228-29, 231, 240-42, 249 (1985).

${ }^{89}$ See Winter, Contingency, supra note 3, at 1003-04.

90 See Radin, The Pragmatist and the Feminist, 63 S. CAL. L. REv. 1699, 1710-11, 1722-25 (1990); see also Michelman, Personal But Not Split: Radin Versus Rorty, 63 S. GAL. L. REV. 1783, 1792-94 (1990).

91 See Post, The Constitutional Concept of Public Discourse: Outrageous Opinion, Democratic Deliberation, and Hustler Magazine v. Falwell, 103 HARV. L. REV. 601, 64445 (1990); Winter, Contingency, supra note 3, at 966-67, 969-71, 1000-01.

92 Winter, Contingency, supra note 3 , at 970 . This is the kernel of what has become a standard objection to the Habermasian notion of an "ideal speech situation." See, e.g., J.-F. LYOTARD, THE POSTMODERN CONDITION: A REPORT ON KNOWLEDGE 62-63 (G. Bennington \& B. Massumi trans. 1984).

${ }_{93}$ See, e.g., Putnam, A Reconsideration of Deweyan Democracy, 63 S. CAL. L. REv. 
left by deconstruction cannot honestly or intelligently be ignored. Where can we possibly hope to find the unprescribed yet predialogic "community" required for undominated dialogue?

Following Merleau-Ponty, George Lakoff, and Mark Johnson, Steven Winter has found a possible common ground of this prerequisite intersubjectivity in a human commonality of prereflective cognitive structures. ${ }^{94}$ It is instructive to see how circumspectly Winter has had to treat this material. Suppose one said, simply, that the ground of cognitive intersubjectivity is physical, and that culture is a strictly subordinate process of codification and transmission. Then it would seem that "dialogue" under these conditions could hardly do other than statically exchange the products of these naturalistically rooted, culturally codified cognitive structures. The deconstruction of choice/ necessity, of persuasion/prescription, would reappear in phenomenological dress (that is, in appeals to our introspective experiences of limit, habit, creaturely constitution).

Winter's answer to this phenomenologically modified deconstruction of persuasion/prescription is, one might say, another deconstruction: the deconstruction of nature/nurture that appears in his notion of "slippage." This "slippage" then represents the possibility of dialogue (not just recycling monologue), given physique-based cognitive commonality. ${ }^{95}$ Slippage instigates the evolutionary rise, in sharply differentiating social environments, of epistemic plurality. Winter argues, in effect, that in the condition of postmodernity, ${ }^{96}$ it is now epistemic pluralism, not monism, that poses the problem for normative dialogue. The epistemic distances have grown too great, the ethers too rarified, to allow for any but the merest slivers of persuasive communication across the gaping subcultural fissures in our fractured society. Still (we read Winter as saying), the receding but never completely vanished physical substrates of cognitive likeness always offer-to those who

1671 (1990) (arguing that democracy is a "precondition for the full application of intelligence to the solution of social problems").

94 See Winter, supra note 20, at 1129-50. But see Winter, Contingency, supra note 3, at 1002 ("But if [physical embodiment is all that determines these structures], communication will be very difficult and rudimentary.").

${ }_{95}$ See Winter, Contingency, supra note 3, at 996-98. Schlag uses the term "slippage" in a quite different, quasi-structuralist sense to mark "the diagonal transversal movement of the same force . . . across the conventional reified sectors that mark our world ...." Schlag, Politics of Form, supra note 2, at 910.

${ }_{96}$ See D. HARVEY, THE CONDITION OF POSTMODERNITY 76-77, 116-17, 302-05 (1989). 
will trouble to understand them-the hope of slowly, laboriously, inching towards the cognitive community on which undominated dialogue depends. Winter joins Habermas. ${ }^{97}$ Poststructuralism joins pragmatism.

\section{The Poststructuralist-Pragmatist Dialectic}

We have been distinguishing two ideal-typical aspects"poststructuralist" and "pragmatist"-of what we regard as one critical practice. Now if we look at these two aspects from a poststructuralist perspective, we can easily see that they cannot be held apart. The poststructuralist/pragmatist distinction as we structured it will (as expected) collapse.

When the poststructuralist-minded practitioner observes the conceptual structures of a discourse practice, preparatory to attacking its analytic probity, what does she-what could sheobserve but contingent features of her own discourse? Concepts are distinguishable by us only relative to discourses in which we participate (and which participate in us); there is no discourse we can deconstruct except our own discourse in use at the moment. But there is no discourse in use except colloquially, by people sharing some particular form of life. So the poststructuralist critic is limited to detailed observation, from within a form of life, of practices embedded in that form of life. ${ }^{98}$ And as poststructuralism is a practice of immanently self-critical reflection, so poststructuralist critical practice coalesces with pragmatist critical practice.

Now switch back to the pragmatist moment. When we evaluate styles of argument in a pragmatist frame of mind, we look for salient features in use; we look for successes and failures at coping with the problems that life actually presents. We do not then see poststructuralist criticism and pragmatist criticism as logically or inherently separate, but we do see them as representing, as we have said, different strains of temperament and different moments in critical practice. When we are practicing pragmatically, we notice

97 "[T]heory can locate a gentle but obstinate, a never silent although seldom redeemed claim to reason, a claim that must be recognized de facto whenever and wherever there is to be consensual action." J. HABERMAS, COMMUNICATION AND THE EVOLUTION OF SOCIETY 97 (T. McCarthy trans. 1979).

${ }^{98}$ Cf. M. WALZER, INTERPRETATION AND SOCIAL CRITICISM 39 (1987) ("[T] outsider can become a social critic only if he manages to get himself inside . . . local practices and arrangements."). 
differences in philosophical temperament, try to take them seriously, try to hold them apart for long enough to ask what ramifications they have for our lives.

Structures or discourses that dissolve into each other conceptually may nevertheless tend in experience to be stubbornly different. ${ }^{99}$ It is not that someone temperamentally inclined towards deconstruction never looks to how problems are solved in practice, and it is not that someone temperamentally inclined towards (re)construction never faces up to structural incoherence. It is just that in practice we often find that those temperamentally inclined to poststructuralism emphasize the moves that confound our categories and shake our certainties, and those temperamentally inclined to pragmatism emphasize the moves that can function as ameliorative guidelines for ongoing projects.

In practice, it is useful to separate, sometimes, the poststructuralist and pragmatist moments in criticism. (Being of pragmatist temperament or at least in a pragmatist phase of mind at the moment, we think so. ${ }^{100}$ ) We are talking about characteristic leanings, or habits of thought, not about logical necessity or entailment; but when it comes to thinking about the characteristic limitations of a discourse as it is used by imperfect practitioners, distinguishing these habits of thought can be important.

${ }^{99}$ See infra notes 104-05 and accompanying text (discussing rules).

${ }^{100}$ Since we are speaking here of a dialectic, we should also note how the pragmatist moment can swing back to the poststructuralist. That switch comes when the pragmatist sees culture's grip on the characteristic instabilities of a discourse as relentless enough to count as collapse of the discourse. For example, our account, above, of the pragmatist critic's cautions to the complacent legal economist, see supra notes 60-62 and accompanying text, might be taken as deconstructive criticism. Our account, below, of pragmatist critical caution to complacent pragmatists, see infra notes 106-11 and accompanying text, presents a more complex case. The charge that complacent pragmatist jurisprudence entrenches bad coherence is deconstructive, and it approaches the point of suggesting that the entire discourse together with all its works is infested with subordinative tendency. Yet it stops short of that point when it expands the field of pragmatic normative observation from institutional acts to extra-institutional life and suggesis the destabilizing potential of the incoherence of actual social life with institutionally professed ideals. See Radin, supra note 90, at 1709-11, 1720-21. 


\section{MORE CRITIQUeS OF NORMATIVITIES}

New wave assaults on "normative legal thought" so far have tended to chart their campaigns around the citadel of foundationalistic grand theory. ${ }^{101}$ So far, they have said relatively little about legal scholarly normativities that have already crossed over (professedly, at any rate) into postmodernist anti-foundationalism: not only poststructuralism, but also pragmatism and (for the most part) feminism and critical race theory. It's not that such normativities are placed beyond any need for critical attention. ${ }^{102}$ It may rather be that on the map of legal thought mercatorized around formalistic-deductive-prescriptive grand theory, they're Antarctica. Only dedicated specialists visit Antarctica.

To be spared critical attention is to be ignored. Neglect is not always benign, although sometimes it is. In other words, there is always waiting to be made a pragmatic judgment about whether now is a good time to place feminist jurisprudence, say, or critical race theory, under critical inspection. All jurisprudences have structural instabilities that poststructuralists could address, and practical liabilities and limitations that pragmatists could address. It is always open to question whether addressing them is, at the moment, a useful thing to do.

Reflecting on this question, we notice an important reason to work at holding the pragmatic moment in critical practice together with the poststructuralist one rather than let the two fly asunder into separate undertakings. There seems to be a consequential difference between the kind of theoretical checkmate that a "pure" deconstructive critique can be taken (if often mistakenly) to intend and the kinds of (re)constructive cautions in practice that occupy the pragmatic critical moment. Not wishing to demotivate some insurgent, perhaps congenial, jurisprudential practice, a "pure" poststructuralist critic might see no other choice but giving that practice the silent treatment. With a pragmatist moment also in view, the options may not seem so limited.

101 See supra notes 4-10 \& 19-21 and accompanying text.

102 See, e.g., Schlag, Politics of Form, supra note 2, at 888-91 (discussing the failures of pragmatist and poststructuralist critical practitioners to "examine ... the social, cognitive, and rhetorical scene of their own thought"). 


\section{A. Pragmatist Self-Reflection}

One weakness to which the pragmatist temperament is prone is a disabling radical particularism. The nonideal pragmatist, awash in formalist/legalist culture, too lazily thinks that since rules can't possibly be what that culture says rules have to be in order to be any good at all-that is, fact-independently and precontextually operative-then we had better keep away from rules altogether. From rejection of the formalist conception of ruleness, the nonideal pragmatist may leap (unpragmatically) to the conclusion that all notions of ruleness are misleading, all pretenses of ruleness misdirected. In other words, she may try to practice the rule that case-by-case judgment, situated decisionmaking moment by moment, describes all there is and can be to practical, active intelligence. She may embrace the rule that attempting to implement rules is always bad (not useful) and attempting to decide by case-by-case judgment is always good (useful).

This denial of the possibilities for rules yields a kind of nominalist intuitionism. What can someone in this stance give as a reason for her decision other than she just looked out at the world at the given moment and grokked ${ }^{103}$ the answer? How can her acts and decisions have any aim if there are no generalizations linking one to another? The radical particularist stance, however tempting to pragmatists tilting with formalism, is at odds with the pragmatic spirit of problem-solving for human needs, considered in the broadest sense. The complete pragmatist will doubt that unaided radical particularism can accomplish much good for human beings. ${ }^{104}$

Radical particularism is incomplete pragmatism because it shirks the hard pragmatic work of calibrating ruleness to context. It shirks consideration of the nature and uses of rules and generalizations,

${ }^{103}$ In one of Robert A. Heinlein's mid-century science fiction novels, "grok" signified a mode of unmediated communication or infallible understanding. See $R$. HeInlein, Stranger IN a STRANGe LAND (1961); $f f$. Gabel \& Kennedy, Roll Over, Beethoven, 36 STAN. L. REV. 1, 4-14 (discussing "intersubjective zap").

${ }^{104} \mathrm{Just}$ as pragmatism has a seli-critique for excessive rule-skepticism (issuing in radical particularism), so it has a parallel self-critique for excessive revulsion from normative "general theories" of law (issuing in radical eclectic normative opportunism). For a good discussion, see Farber \& Frickey, Practical Reason and the First Amendment 34 UCLA L. REV. 1615, 1628 (1987) ("Pure eclecticism makes the first amendment too legalistic, too much the domain of specialized lawyers .... [T] [Te first amendment as a whole should stand for something worthy of ultimate commitment."). 
once we know what those are not and cannot be. In a fuller pragmatic understanding, while rules cannot be hard-and-fast as the formalist conception supposed, they can be working presumptions that in practice may be quite hard-and-fast under the circumstances. ${ }^{105}$ Presumptively, there are circumstances when hardand-fast rules (in the pragmatic sense) will be useful and (relatively) benign, although no algorithm can decide for us when.

Another weakness that sometimes appears in the work of mainstream legal pragmatists is taking the status quo for granted. Unwilling to part with the notion of truth, unable to believe that truth can possibly consist in thought's correspondence with thoughtindependent existence, pragmatists have often repaired to a notion of truth as coherence. In concept, this means the systemic, propositional coherence of everything we would right now take as being the case if we thought about it. In practice, it means the consistency of a doubted proposition with everything else we consciously stand ready, right now, to affirm. ${ }^{106}$

For the formalistically acculturated pragmatist jurisprude, the search for coherence may confine itself to the institutional status quo, the totality of existing institutions and institutionalized practices. The search may omit the extra-institutional, cultural contradictions, the ethical dissatisfactions, the unmet ideals, the critical visions that also inhabit and enliven our totality. Thus coherentism may turn into complacent or aggressive conventionality $^{107}$ or traditionality. ${ }^{108}$ Perhaps the incomplete pragmatist

${ }^{105}$ See Radin, Reconsidering the Rule of Law, 69 B.U.L. REV. 781, 795, 804, 806 (1989) (discussing the formalist conception of rules); Schauer, Rules and the Rule of Law (forthcoming 14 HARV. J.L. \& PUB. POL'Y (1991)) (proposing "presumptive positivism").

${ }^{106}$ Note that coherence theory is contested among pragmatists; this may be due to differing constructions of coherence. See Radin, supra note 90, at $1708 \mathrm{n} .26$.

107 The difference between complacent and aggressive conventionality shows up in the dispute between Stanley Fish and Owen Fiss. See, e.g., Fiss, Conventionalism, 58 S. CAL. L. REv. 177, 184 (1985) [hereinafter Fiss, Conventionalism] (Fiss explaining that he and Fish "use the concept of an interpretive community differently-[Fiss sees] it as a source of authority for the disciplining rules, and Fish sees it as the source of shared understandings [making disciplining rules unnecessary]."). For the Fish-Fiss dispute, see Fish, Fish v. Fiss, 36 STAN. L. REv. 1325 (1984); Fiss, Objectivity and Interpretation, 34 STAN. L. REV. 739 (1982).

108 See, e.g., 1 F. HAYEK, The FATAL Conceit: THE ERrors of SOcIalism ch. 1 (1988) (arguing that traditionally evolved rules of human conduct in selectively successful civilizations deserve strong presumptive respect); 3 F. HAYEK, LAW, Legislation and LiberTy: The Polrtical ORder of a Free People 153-76 (1979) (same); Michelman, Saving Old Glory: On Constitutional Iconography, 42 STAN. L. REV. 1337, 1356-57 (1990) (explaining Hayekian view). But see Kronman, Precedent and 
jurisprude, anxious for coherence, searches where the scholar's lamp shines brightest, in the archives. Archives collect institutional acts and decisions; they collect precedents. While precedential, institutional incoherence perhaps quiets anxiety, arguable ethical incoherence in life beyond the archives goes unnoticed or at any rate unremarked.

For example, there is the fact that hierarchies of race and sex remain cruelly entrenched, economically, socially, and culturally, in American life. The institutions of law, commending institutional colorblindness, ${ }^{109}$ both proclaim and condone that fact's coherence with the American way. Embracing institutional coherence as the test of truth and justice, the incomplete legal pragmatist may fail to see as ethically outrageous (and, indeed, as incoherent with institutional professions of nondomination) the informal, embedded, trans-institutional oppressions of life in America. She may fail to consider that these oppressions may well be worse, more unjust, than the pockets of institutional incoherence that relief of oppression may really require. ${ }^{110}$

This is indeed a serious criticism, because it charges pragmatists with what in other circumstances can be their salient virtue: working with trees while bracketing forests. Pragmatists do recognize that most of the background must be taken as given in order for the foreground to present itself for work. Yet it is we who partition the world's features into foreground and background, and sometimes it is the habitually most taken-for-granted cultural landscape features that most cry out for redescription. Only by constant attentiveness to the commonplace can pragmatist critical practice keep faith with its postmodernist commitments to suspect facile consensus and pursue epistemic openness. ${ }^{111}$

Tradition, 99 YALE L.J. 1029, 1046 (1990) (rejecting the traditionalist view that the past possesses its own authority).

${ }^{109}$ See, e.g., City of Richmond v. J. A. Croson Co., 488 U.S. 469, 493-96 (1989) (plurality opinion of O'Connor, J.); id. at 520-21 (Scalia, J., concurring).

${ }^{110}$ Even while arguing that legalism is strongly connected to justice, John Rawls notes that in a nonideal situation justice may require relaxation of legalist strictures. See J. RAWLS, A THEORY OF JUSTICE \$ 38, at 242-43 (1971).

${ }^{11}$ See supra notes 86-97 and accompanying text (discussing lazy dialogism). 


\section{B. Feminist Jurisprudence}

Feminism, like critical race theory, arises with a critical goal: showing how other jurisprudences tend to suppress perspectives that are most at home among those in our society who are not white men. In their thoroughgoing embrace of epistemic contention, many feminists and critical race theorists partake of postmodernistpragmatist and poststructuralist-critical practice. Feminism and critical race theory are especially well positioned to drive home the dangers of coherentist complacency. ${ }^{112}$ Conversely, pragmatist reflection offers in return some cautions for feminism and critical race theory.

In response to classical doctrinalism and certain traditional forms of rights theory, many feminists have strongly doubted the value of a priori, rule-like normative structures as compared with situated decisionmaking and acknowledgment of the contingencies of context. Like their pragmatist neighbors, ${ }^{113}$ feminists can be tempted into disabling radical particularism. Moreover, radical particularism can become especially tempting when feminists adopt too rigid a rule that rule-like structures are masculine (to be rejected) and non-rule-like procedures are feminine (to be adopted).

Rule-like procedures are easily identified as belonging to the "ethic of justice," the style of thought in moral decisionmaking that Carol Gilligan contrasted with the "ethic of care" she found to be characteristic of mature women. ${ }^{114}$ Elaborating on these categories,

112 See Minow, The Supreme Court, 1986 Term-Foreward: Justice Engendered, 101 HARV. L. REV. 10, $34-57$ (reviewing five complacent assumptions).

113 See supra notes $103-05$ and accompanying text.

114 See C. GILIIGAN, IN A DIFFERENT VOIGE: Psychological THEORY AND WOMEN'S DEVELOPMENT (1982). The following list may summarize the way the distinction has come to be understood in feminist thought:

Ethic of Care
nonviolence
needs, interests
contextual
responsibility, nurture
attachment, connection
community
interdependence
cooperation
concrete, embedded
perspectival
narrative
intuitive
emotional

Ethic of Justice

equality

fairness, rights

universal

desert, rights

separation, autonomy

individualism

independence

competition

abstract, universal

principled

systematic

logical

rational 
some feminist legal writers have tended to assume that there is something "essentially" womanly about the ethic of care, ${ }^{115}$ and something irredeemably masculine about the ethic of justice.

The pragmatist-feminist objects that this essentializing stance excludes women from a moral tradition that has its redemptive side; ${ }^{116}$ and, moreover, that this exclusion may excessively inhibit any aspirationally inclusive society from trafficking at all with that tradition. Perhaps more importantly, the pragmatist-feminist continues, the essentializing stance tends to entrench a current cultural understanding of women's limited nature, a cultural understanding that many women and men find injurious and want to dissolve. Feminism would thus put itself at odds with its own pragmatic doubt that current cultural constructions of feminine "nature" are separable from the detritus of an oppressive ideology of gender. Worthy and precious as it is, the ethic of care as we know it may also be a cultural complex of traits useful to a group existing under oppression. ${ }^{117}$ Without conceding the indefinite continuation of women's oppression, we cannot regard such a complex as essential or peculiar to women.

We mean this as a typical pragmatic caution, not a terminal deconstruction. The pragmatist-feminist brackets the question of false consciousness. She sees that for women living in patriarchy, women's experience of patriarchal life is partially self-constitutive. She forbears from demanding of women, of herself, the impossible: the self-destroying regimen of constantly remarking, in one's every moment of self-fulfillment as woman, the mark, the trace, of deprivation of self. Not only do those moments of self-fulfillment,

web

hierarchy

See Radin, supra note 90, at 1712-13.

${ }^{115}$ For discussions and critiques of essentialist feminist jurisprudence, see Harris, Race and Essentialism in Feminist Legal Theory, 42 STAN. L. REv. 581 (1990); Rhode, The "No-Problem" Problem: Feminist Challenges and Cultural Change (forthcoming 100 YALE L.J. (1991)).

${ }^{116}$ See supra notes 80-85 and accompanying text (discussing the critique of the critique of rights).

${ }_{117}$ See, e.g., C. MACKINNON, FEMINISM UNMOdified 39 (1987) (arguing that Gilligan's "ethic of care" reinforces women's powerlessness); Wells (formerly Hantzis), Is Gender Justice a Completed Agenda? (Book Review), 100 HARV. L. REv. 690, 700 (1987) (recognizing that because "powerlessness is the central fact of female experience," certain characteristics are more easily projected onto and internalized by women); see also Alcoff, Cultural Feminism Versus Post-Structuralism: The Identity Crisis in Feminist Theory, 13 Signs: J. WOMEN IN CULTURE \& SOC'Y 405, 407 (1988) (criticizing cultural feminism for "defin[ing] women by their activities and attributes in the present culture"). 
lived in patriarchy, partially constitute identity for women in patriarchy, they also constitute the beginning (not the end) of knowledge of a possible better world and determination to strive towards it. Conventional femininity is where we start, it is what we have to work with. No pragmatist would want women to detach thought and action from desire. No pragmatist would want to waste the concrete knowledge wrought by women living, speaking, finding voices, under male domination. The pragmatic alternative to waste and self-defeat is not, however, the exaltation of conventional femininity into essential womanhood. Rather, it is watchful receptiveness to redescription. It is the cultivated understanding that all our old descriptions of the world are always open to progressive change.

\section{Critical Race Theory}

Critical race theory is a pursuit of empowerment through concerted exchange, discipline, consolidation and vocalization of specially acquired and developed knowledge, in a manner suited to that knowledge. It is a cultural "nationalist" project of genre creation. ${ }^{118}$ Its practitioners aim to dislodge cultures of subordination, or at least build resistance to the damage they do to people's lives, by synthesizing in legal scholarship the material and moral experience of subordination from the perspective of the subordinated. ${ }^{119}$ In creating critical race theory, legal scholars of color have created a voice of their own that all have reason to hear. ${ }^{120}$ Needless to say, it is from the perspective of whites to whom critical race theory is partly addressed that we here speak. From our

${ }^{118}$ See Peller, Race Consciousness, 1990 DURE L.J. 758, 791-94 ("Against the liberal image that group identity and status are opposed to ... individual freedom, the nationalist perspective sees in historical structures the very basis for social meaning.").

119 For example, as Richard Delgado explains:

The cohesiveness that stories bring is part of the strength of the outgroup .... For many minority persons, the principal instrument of their subordination is . . . the prevailing mindset by means of which members of the dominant group justify the world as it is .... Stories . . . are powerful means for destroying mindset-the bundle of presuppositions, received wisdoms, and shared understandings against a background of which legal and political discourse takes place.

Delgado, supra note 85, at 2412-13.

${ }^{120} \mathrm{See}$ id. at 2435-40; Michelman, supra note 90, at 1791. We have already provided an example: the telling accounts that voice delivers of the ambivalence of subordinated people's experience of the jurisprudence of rights. See supra notes 80 82 and accompanying text. 
perspective, there appears to be a pragmatic problem, a double bind, ${ }^{121}$ facing critical race theory. From our perspective, the danger is that of playing into bad old cultural categories of subordination. The danger lies in the difficulty and delicacy of judgment, at a given time and place, of the current, local state of culture among those who in the circumstances have power to make "cultural meaning" that inflects the self-understandings of others around them. ${ }^{122}$ How far has the meaning-making community really progressed towards a cultural pluralist outlook, ${ }^{123}$ one that is nationalistically attuned yet truly destratified?

Behind the work of critical race theorists lies bitter knowledge of the depth of entrenchment of stratified cultural categories, and so for them there must always still be the question of whether stratification here, now, remains entrenched in such a way as to turn cultural nationalism against itself. For example: Where stratification remains deep-where the prereflective common ground of undominated dialogue is thin, remote, and uncertain ${ }^{124}$-scholarly accentuations of group identity may be heard as suggestions that faculty candidates of color ought be judged, in part, by conformity to a cultural mode that someone constructs as, say, Black. Under present conditions in legal academia, with very few exceptions, any such constructions will come from the minds of (predominantly white) people in "predominantly white" (which is to say white, not yet multicultural) social settings. Moreover, those minds-our minds-cannot be unambiguously, securely proof against the virus, the heritage, of patronage. It seems that inviting $u s$ to say who is and who is not culturally "of color," as we go about (re)populating our institutions, should not routinely be considered a sure and safe path toward desubordination. (1991)).

${ }^{121}$ See Radin, Affirmative Action Rhetoric (forthcoming 8 Soc. PHIL. \& POL'Y

${ }_{122}$ See Lawrence, The Id, the Ego, and Equal Protection: Reckoning With Unconscious Racism, 39 STAN. L. REV. 317, 321 (1987). Many scholars of color argue (we find compellingly) that, in American society, belonging to a group that is culturally identified, qua group, as not-white is a special experience that may yield perspectives warranting the most serious attention from all. See, e.g., Matsuda, Public Response to Racist Speech: Considering the Victim's Story, 87 MICH. L. REV. 2320 (1989). At the same time, scholars of color argue (also compellingly) that sometimes, at least, accentuation of group membership just envenoms the sting of subordination. See, e.g., Carter, The Best Black, and Other Tales, RECONSTRUCTION, Winter 1990, at 6.

${ }^{123}$ See Kennedy, A Cultural Pluralist Case for Affirmative Action in Legal Academia, 1990 DUKE L.J. 705, 757.

124 See supra notes $95-97$ and accompanying text. 


\section{Poststructuralism}

Taken unpragmatically, deconstruction may look like a critical practice that cannot be trained inward upon itself and live to tell the tale. That observation would certainly not mean that poststructuralist critical practitioners cannot critically reflect on their own practice. Rather, it might mean that when they do, they do so pragmatically. (For us, a memorable and telling example is Schlag's pragmatic refusal to be silenced by the charge of performative contradiction. ${ }^{125}$ ) Here we offer some additional specifics of pragmatist caution to poststructuralist practice.

Against which characteristic errors or biases would pragmatist critics want to warn poststructuralists (including themselves when they are being poststructuralists)? Two present in our legalacademic context are the dangers of (1) inapt structuralism and (2) skeptical paralysis.

If a strength of deconstruction is to disabuse us of rigid dichotomies, a corresponding danger is to see (construct) rigid dichotomies in places where our discourse is saliently more complex, more "continuum-ized." Deconstruction itself maps structure onto the thought it deconstructs, rendering that thought into bimodal categorical form. ${ }^{126}$ It is good to put bimodal categories to the test where these exist in our discourse, ${ }^{127}$ but deconstruction may be less useful if applied where usage is already less bimodal. In some cases, in other words, deconstruction may obscure rather than clarify our situation vis-à-vis our own discourse.

An example may be seen in recent debates over rules and rulefollowing. It seems that incomplete poststructuralism muddies the waters by entrenching-even while deconstructing, and indeed in order to deconstruct-an overconfident distinction between "rules" and "standards." The pragmatic point of deconstructing a rules/ standards distinction is of course to help us see that indeed these cannot be distinct and rigid categories. But under the circumstanc-

125 See Schlag, The Politics of Form, supra note 2, at 925 ("[W] $[$ here don't you go, what do you miss, if you keep trying to avoid performative contradictions?"); see also id. at 888-93 (pointing out how legal pragmatists and deconstructionists fail to examine the academic institutional-cultural contexts and determinants of their own practices); supra notes $16-17$ and accompanying text.

${ }^{126}$ See Balkin, supra note 49, at 746 ("Described in its simplest form, the deconstructionist project involves the identification of hierarchical oppositions, followed by a temporary reversal of the hierarchy.").

${ }^{127}$ See, e.g., Schlag, Politics of Form, supra note 2, at 826-28 (deconstructing the opposition of "technical doctrinalist" and "moralist" jurisprudence). 
es, it may be possible simply to observe our discourse carefully and notice that these categories already do not seem rigid to us. Pragmatically, we do not need to create a binary opposition in order to disabuse ourselves of it. Moreover, the attribution of a binary opposition tends to reinscribe the traditional philosophical view that there is, indeed, a "logical" distinction between "rules" and other kinds of directives addressed to agents. The more useful postWittgensteinian position, and the better way to deny the existence of any such "logical" distinction, is to understand our discourse and activities involving rules and rule-oriented behavior as distributed along a continuum. ${ }^{128}$

Another sort of incompletion to which poststructuralist practice is liable ends in skeptical loss of valuational focus or political direction. Deconstruction as an "edifying" discourse has been used in the service of emancipatory social change. For example, when it is shown that the feminine, as a dangerous supplement to the masculine, cannot be held outside, but is always already inside the masculine, ${ }^{129}$ then this, the poststructuralist critic reasonably hopes, will help us stop privileging the masculine. But there is nothing that could make deconstruction "by its nature" progressive. Anything can be privileged, and anything can be deconstructed. Some of the conceptions we privilege may be good (in their places) and some may be bad, but this is not something deconstruction can tell us; from inside the deconstructive perspective, characterizations of one conception or another as "good" or "bad" are not coherently understandable except as more fodder for deconstruction. Deconstruction can open the way to new understandings and hence social change, but it cannot help to guide the direction of change or say whether change (however guided) will be for the "better" or "worse." ${ }^{130}$ Each new understanding can be deconstructed with the very same vigor as the one it replaces.

Of course, something must be privileged for deconstruction to take place. Something must be privileged if we are to speak and understand each other, if we are to understand the deconstructer as saying something. We must assume a common language, and common language must have some fixed points-some points we

128 See F. SGhauer, Playing by the Rules: A PHILosophical EXamination of RULE-BASED DECISIONMAKING IN LAW AND IN LIFE (forthcoming 1991).

129 See, e.g., T. EAGLETON, LITERARY THEORY: AN INTRODUCTION 132-33 (1983) (deconstructing the man/woman opposition).

${ }^{130}$ See supra notes 73-85 and accompanying text (critiquing the critique of rights). 
select (or have had selected for us) as fixed points, even if we fail to notice the selection happening. Poststructuralists are often ironically aware of how they willy-nilly reflect such selections as they write, and how their readers do the same as they read. ${ }^{131}$ Yet the imperfect poststructuralist may suppress this ever-present irony. She can forget sometimes that, in her own very act of writing, the same kind of privileging that she deconstructs in others must always already be going on in order to enable her to write-or even to be.

So, imperfect poststructuralist writing can tend to be selfprivileging. This failing can extend to the privileging of the methodology itself. Like the skeptic who forgets to be skeptical about the "truth" of skepticism, the poststructuralist-minded critic may lapse rhetorically into implying that there is something good or right about deconstruction itself, privileging deconstruction, making it foundational..$^{132}$

Such implications risk not only communicative misunderstanding, ${ }^{133}$ but dissipation of reformist political will. A conception of politics in which it is intelligible for politics to be "progressive," to aspire to creation of communities that empower human beings, is hard to couple with a conception of politics that cannot make sense of a commitment to work toward a vision of a better future. To sustain political motivation, better reason must exist to dislodge the status quo than the mere fact that it is the status quo. That better reason can only be our vision of a better future; yet no vision can motivate if it always arrives already (atemporally, foundationally, irreparably, terminally) deconstructed. ${ }^{134}$

\section{CONCLUSION: TOWARD (RE)CONSTRUCTION}

We have just been speaking of poststructuralism as a critical practice of, and in, legal scholarship. Let us say there is in our world a cultural space occupied by what we all know as law and legal ordering. By and large, legal scholarly antagonists of various normativities in legal thought simply cannot be construed as calling for an evacuation, or a surrender to others, or a closing down of the legal-cultural space. Their work cannot be construed as bespeaking

131 See, e.g., Schlag, Normative and Nowhere to Go, supra note 3, at 843 ("Normative legal thought enables, shapes, and distorts all legal thought, including [this article]. ${ }^{n}$ ).

132 See supra notes 48-49 and accompanying text; infra note 137 and accompanying text.

133 See supra notes 11-18 and accompanying text.

134 See infra notes $139-41$ and accompanying text. 
the cessation of efforts to achieve goals through activities located within-filling-that space; rather, their productions exemplify critical work within that space, or work on redefining its boundaries. ${ }^{135}$ Many critics of one or another normative jurisprudence evidently mean to reject the jurisprudence(s) they criticize in favor of some other, perhaps too hastily deemed exempt from critique by virtue of, say, its postmodernist commitments to anti-foundationalism, immanence, historicity, and epistemic struggle. Perhaps, for example, they reject classical doctrinalism or dialogism in favor of pragmatism, or feminism, or critical race theory.

Other critical practitioners evidently try to abstain from commitment to any jurisprudence and devote themselves abstemiously to excavating the hidden, mystifying, self-enclosing, but also self-liquidating, structures they know (and so do we) they can find in every candidate jurisprudence that comes along. ${ }^{136}$ We think even their practice cannot be non-normative in the broadest sense in which some of them use the term, because (as we explained in Parts I and II) no discursive utterance-and in particular no argument-can be seriously entertained as non-normative in so broad a sense. Still, these most fastidious critical practitioners apparently try to refrain from ever saying explicitly that there is anything we ought to do; they confine their arguments to assault on (other) normative frameworks. Are their arguments, then, perhaps non-normative in a pragmatic sense, since they refrain from inviting us to do anything (except engage with them)?

135 See Schlag, Politics of Form, supra note 2, at 843 (placing inside the force field of the system of normative legal thought "that sort of thought which (like this very article) seems so far removed, so distant from the paradigmatic case"). Of course, there has been a good deal of hearifelt protest over the recent critical-theoretical turn in the scholarly devotions of the employees of law schools. But the authors in this symposium obviously don't want to be understood as reading critical legal scholarship out of the canon of the properly legal. Insofar as by "normativity" in legal thought they might be taken to mean the legalism of that thought, they still must mean to allow for legal scholarship that is counter-legal, anti-legal, beyond or against the conventions of the going-concern discipline of law (as those are presented, for example, in Fiss, Conventionalism, supra note 107, at 194-95 (1985); Fiss, The Death of the Law?, 72 CORNELL L. REv. 1, 9-1.3 (1986)). They mean to insist that such counterlegal(ist) normativities fall within, rather than without, the field of "legal" scholarship. They are not offering to abandon the field of legal work-their field, our field-to the legalist adversary. Obviously, law professors will speak more effectively if perceived as doing law controversially than if perceived as not doing law.

${ }^{136}$ See, e.g., Schlag, Politics of Form, supra note 2, at 932 ("[This article is] an attempt to help destabilize normative legal thought. . . . [T] This process is not pleasant ... . [But i]t happens all the time. ... . It's the law."). 
It has, after all, been said by way of explaining such a determinedly negative practice that it is just, well, fun. ${ }^{137}$ But of course that is rarely, if ever, all that's said or intimated by way of explanation. The more satisfying explanation, the explanation that allows this critical practice to retain its momentum and its audience, is different. It is pragmatic. (Of course, it is poststructuralist, too.) And it is normative. It is the belief-the situated judgment-that under current conditions, normative projects are bound to the reproduction of evil until relentless application of the negative can break the grip on our acculturated imaginations of a particular, historically situated, pernicious world-view. ${ }^{138}$

Thus understood, anti-normativism is not foundational; it is only temporarily and not atemporally privileged. Thus understood, antinormativism is a pragmatically inflected project. Those who still attack all jurisprudences and embrace none must be judging in context that the moment for reconstruction is not yet here. When and for whomever that moment does arrive, the conceptual truth that each and every normative project is liable to deconstruction no longer works as a foundational objection against engagement in such projects; it becomes just one more problem to be understood and negotiated. ${ }^{139}$ When and for whomever that moment comes, the perpetual anticipation of mockery no longer counts as a reason

137 See Freeman, Truth and Mystification in Legal Scholarship, 90 YALE L.J. 1229, 1230 (1981) ("[T]rashing is fun. I love trashing . . . .").

138 See, e.g., id. at 1230-31 (explaining that "the point" of trashing is exposure of possible notions of justice better than the currently prevailing "abstract, rightsy, traditional, bourgeois" notion); Schlag, Normative and Nowhere to Go, supra note 3, at 181 (presenting deconstruction of normative legal thought as a project of "disenchantment"); $i d$. at 188 (stating that "[u]ntil normative legal thought begins to deal with its own paradoxical postmodern rhetorical situation, it will remain ... an irresponsible enterprise").

${ }^{139}$ In the following passage, substitute anti-normativists for sentimentalists/ utopians and substitute pragmatist (hell, substitute normative) legal thought for positive theory of law:

[N]ote should be taken of the unhappy fate of natural-law doctrines and assorted other excursions into "revolutionary" legal theory. The revolutionary bourgeoisie . . . counterposed natural-law doctrines to feudal theory but once in power rushed to embrace a positive theory of law .... However much sentimentalists and utopians may rail at the monotonous recurrence of a positive theory of law whenever revolutionaries settle down to rebuild the world they have shattered, any other course would be doomed to failure. E. Genovese, Roli, Jordan Roll: The World the Slaves Made 26 (1972). 
to quit. ${ }^{140}$ It remains, of course-an ambiguity that we live with, a risk that we take.

It seems a possibility worth considering that there is not, and is not going to be, any critical speaker for whom the reconstructive, the visionary, the committed moment is not always already coming, and thus is not always already here. ${ }^{141}$ We can deconstruct because we can reconstruct; we are anti-normative insofar as we are normative. As the reconstructive moment seems ineradicable, so too does the human experience of agency. It seems, in other words, a possibility worth considering that the problematic, elusive, "humanist" experience of subjectivity-agency-is an historically irreversible, inexpungible, constitutive aspect of our experience of (human) being. Part of what we do, as concept-making strivers caught in forms of life, is think about the good-the better-world and ourselves acting towards it. We cannot deny our own agency. (We cannot speak the sentence of denial except as speaking subjects, affirming by speaking the sentence what the sentence means to deny.) We can call agency into question, and we had better, but to call into question is also to (re)affirm, (re)create, (re)construct.

140 See Schlag, Normative and Nowhere to Go, supra note 3 , at $167\left({ }^{\circ}[\mathrm{H}]\right.$ is unmistakably derisive tone indicated that [being a 'liberal humanist'] was not something I was supposed to like. So I quit ....").

141 "Only selves can put the self in question-there is literally no one else to do it. And only selves with preexisting commitments (political or otherwise) would engage in such a project." Balkin, Tradition, Betrayal and the Politics of Deconstruction, 11 CARDOZO L. REV. 1613, 1629 (1990); $c f$. H. PUTNAM, REASON, TRUTH AND HisTORY 162-63 (1981) (presenting pragmatist arguments that refute skepticism and relativism on the grounds that they are self-defeating). 